\title{
Paediatric papillary thyroid cancer: what to expect?
}

\author{
Nádia Silva (ㅈ, Nuno Monteiro, Paula Tavares, Jose Coutinho
}

Cirurgia, Centro Hospitalar de Lisboa Central EPE, Lisboa, Portugal

\section{Correspondence to}

Dr Nádia Silva;

nadia.silva@chlc.min-saude.pt

Accepted 22 February 2021

\section{DESCRIPTION}

Papillary thyroid cancer is a rare tumour presentation in paediatric age, and although its incidence is rising, it accounts for $1.4 \%$ of all malignancies in this age. ${ }^{1}$

The presentation of this differentiated thyroid tumour in paediatric age is often linked to lymph nodes and pulmonary metastases. The latter generally is diagnosis after radioactive iodine as they are normally not seen in X-ray or CT scans. ${ }^{23}$

The prognosis is good when the optimal treatment is provided. The treatment derived from the experience in adult population since this is a rare tumour in children. ${ }^{24}$

We present a case of 12 -year-old female patient with a papillary thyroid cancer that was submitted to total thyroidectomy with central compartment lymphadenectomy (figure 1). The first and only complain that lead to the diagnosis was enlargement of the thyroid gland. During utrasound, it showed a highly diffuse Doppler signal throw out the thyroid (figure 2). This was confirmed in the histological result where there was a lymphoid papillary tumour dissemination all over the gland. Of the 20 lymph nodes resected, 16 present metastases (figure 1).

She started radioactive iodine with good final overall result. No signs of metastases were found in the 6-month postsurgical intervention.

The patient had no family history of hereditary tumours, including thyroid cancer. The patient is awaiting results of genetic testing.

This case makes awareness for the diagnosis of thyroid tumour in paediatric age. The principal differences of presentation compared with adults are:
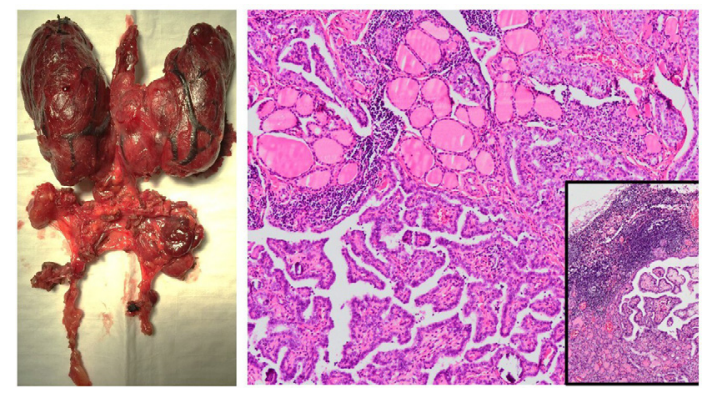

Figure 1 Total thyroidectomy with central compartment lymphadenectomy. There are enlarged lymph nodes in the group of nodes resected (at the left). At the right, we can see in $\mathrm{H} \& \mathrm{E}$ stain the thyroid gland with multifocal conventional papillary thyroid carcinoma. Inset: lymph node metastasis with merging of papillary and follicular patterns.

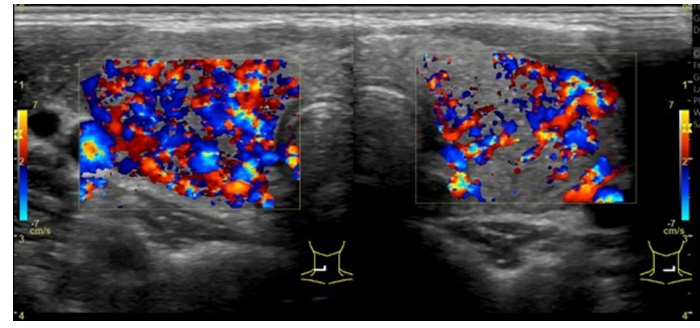

Figure 2 Doppler signal in both thyroid lobes indicating diffuse papillary tumour disease.

- Advanced disease at presentation as shown in figure 2.

- Need for total thyroidectomy and central compartment lymphadenectomy because of frequent lymph node metastases as shown in figure 1 .

\section{Learning points}

- The papillary thyroid tumour is rare in paediatric age but generally presents with lymph nodes metastases at the time of diagnosis.

- Total thyroidectomy with central compartment lymphadenectomy is necessary.

Acknowledgements I would like to thank on behalf of all authors Dr Eduardo Dutra, from the Department of Anatomic Pathology for his help and support in the construction of the article.

Contributors NS conceived the idea, developed and took the lead in writing the manuscript. NM provided critical feedback and helped shape the manuscript. PT and JC supervised the work. All authors discussed the results and contributed to the final manuscript.

Funding The authors have not declared a specific grant for this research from any funding agency in the public, commercial or not-for-profit sectors.

Competing interests None declared.

Patient consent for publication Obtained.

Provenance and peer review Not commissioned; externally peer reviewed.

ORCID iD

Nádia Silva http://orcid.org/0000-0002-6374-626X

\section{REFERENCES}

1 Hogan AR, Zhuge Y, Perez EA, et al. Pediatric thyroid carcinoma: incidence and outcomes in 1753 patients. J Surg Res 2009; 156:167-72.

2 Clement SC, Kremer LCM, Links TP, et al. Is outcome of differentiated thyroid carcinoma influenced by tumor stage at diagnosis? Cancer Treat Rev 2015;41:9-16.

3 Rivkees SA, Mazzaferri EL, Verburg FA, et al. The treatment of differentiated thyroid cancer in children: emphasis on surgical approach and radioactive iodine therapy. Endocr Rev 2011:32:798-826.

4 Francis GL, Waguespack SG, Bauer AJ, et al. Management guidelines for children with thyroid nodules and differentiated thyroid cancer. Thyroid 2015;25:716-59. 
Images in...

Copyright 2021 BMJ Publishing Group. All rights reserved. For permission to reuse any of this content visit https://www.bmj.com/company/products-services/rights-and-licensing/permissions/

BMJ Case Report Fellows may re-use this article for personal use and teaching without any further permission.

Become a Fellow of BMJ Case Reports today and you can:

- Submit as many cases as you like

- Enjoy fast sympathetic peer review and rapid publication of accepted articles

Access all the published articles

Re-use any of the published material for personal use and teaching without further permission

Customer Service

If you have any further queries about your subscription, please contact our customer services team on +44 (0) 2071111105 or via email at support@bmj.com.

Visit casereports.bmj.com for more articles like this and to become a Fellow 